\title{
MONOCYTES/MACROPHAGES ACT AS MEDIATORS FOR HUMAN HERPESVIRUS-6 INFECTION OF THYROID GLAND IN PATIENTS WITH AUTOIMMUNE THYROIDITIS
}

\author{
Lỉba Sokolovska ${ }^{1}$, Alina Sultanova ${ }^{1}$, Maksims Čistjakovs ${ }^{1}$, Egils Cunskis ${ }^{2}$, \\ and Modra Murovska ${ }^{1}$

\footnotetext{
${ }^{1}$ Institute of Microbiology and Virology, Rīga Stradiṇš University, 5 Rātsupītes Str., Rīga, LV-1067, LATVIA

${ }^{2}$ Rĩga East University Hospital, Clinical Centre "Gaiḷezers", 2 Hipokrāta Str., Rīga, LV-1038, LATVIA

Coresponding author, liba.sokolovska@rsu.Iv
}

Contributed by Modra Murovska

\begin{abstract}
The aim of this study was to investigate the possibility of using monocytes/macrophages as mediators in human herpesvirus-6 (HHV-6) infection of thyroid gland tissues in autoimmune thyroiditis (AIT). Seventy-three AIT patients were enrolled in this study. The control group consisted of 80 blood donors. Monocyte/macrophage isolation for AlT patient samples was performed by adherence. HHV-6 was detected in peripheral blood mononuclear cell (PBMC) DNA samples using nested polymerase chain reaction (nPCR). Gene expression of HHV-6 active infection marker (U79/80) and chemokine receptors (U12, U51) in patient monocyte/macrophage samples and blood donor PBMC samples was detected using reverse-transcription PCR. HHV-6 viral load was detected by using quantitative-PCR technique. The HHV-6 genomic sequence was found significantly more frequently among AIT patient than control group samples. Markers of active infection were found in 8 AIT patient monocyte/macrophage samples (11\%) and in none of control group PBMC samples. HHV-6 U51 mRNA expression was detected only in AIT patient samples (2/24 previously positive for HHV-6). Since HHV-6 genomic sequences were found significantly more frequently in AIT patient samples and active infection markers were found in patient monocytes/macrophages, our results suggest that monocytes/macrophages may be used by HHV-6 as mediators for thyroid gland infection.
\end{abstract}

Key words: $H H V-6$, autoimmunity, thyroid gland.

\section{INTRODUCTION}

Human herpesvirus-6 (HHV-6) is widely distributed in the general population $-95 \%$ of individuals in the world have acquired HHV-6 infection at some point in their lives. The primary infection usually occurs in the early years of life and remains latent throughout life (Costa et al., 2011). Originally HHV-6 was divided into two groups, variant A (HHV-6A) and variant B (HHV-6B). However, in 2012 the International Committee on Taxonomy of Viruses (ICTV) decided to recognise both variants as different species (Ablashi et al., 2014).

HHV-6 is known to have strong immunomodulating properties, which could affect the host during a long period of time and contribute to several autoimmune disorders, in- cluding autoimmune haemolytic anaemia/neutropenia (Yagasaki et al., 2011), autoimmune acute hepatitis (Grima et al., 2008) and multiple sclerosis (Chapenko et al., 2003; Tejada-Simon et al., 2003). Recent studies pay more and more attention to the possible involvement of human herpesvirus-6 in autoimmune thyroiditis (AIT) development (Rizzo et al., 2016; Caselli et al., 2017; Sultanova et al., 2017). The contribution to several autoimmune diseases and its widespread distribution, make HHV-6 an important threat to overall health and quality of life.

Our recent study showed a very high frequency rate (99\%) of HHV-6B genomic sequence detection in AIT patient thyroid gland tissues in comparison to the control group samples $(77 \%)$ and $41 \%$ of AIT patient tissues contained mark- 
ers of HHV-6 active infection (presence of HHV-6 U79/80 mRNA), while only $6 \%$ contained the marker in the control group (Sultanova et al., 2017). Another finding of our previous studies was a significant difference in the presence of HHV-6 genomic sequence in thyroid gland tissues and peripheral blood mononuclear cell subpopulations, where no signs of virus presence were found in CD4+/CD8+ T lymphocytes, which are considered as the main target cells for HHV-6 (Sultanova et al., 2016). The absence of HHV-6 in the main $\mathrm{T}$ cell population led to a theory that HHV-6 could potentially persist in monocytes/macrophages. There are studies that indicate monocytes/macrophages as important sites for HHV-6 persistence during acute infection and putative chemokine receptor HHV-6 U12 and U51 gene expression has been detected in these cells (Kondo et al., 2002; Murakami et al., 2010). HHV-6 U12 and U51 gene expression could help HHV-6 to avoid the immune response and to use monocytes/macrophages as vectors for infection of solid tissues during immune cell migration to the site of inflammation (Kondo et al., 2002).

The aim of this study was to determine the presence, activity and immunomodulating potential of HHV-6 in monocytes/macrophages isolated from patients with autoimmune thyroiditis.

\section{MATERIALS AND METHODS}

Patients used in the study. Seventy-three patients with autoimmune thyroiditis (AIT) were enrolled in this study. The patient group included three males (4\%) and 70 females $(96 \%)$, with median age of 52 (Interquartile range [IQR]: 42-60). The control group included 80 blood donors, of whom 50 were males (62\%) and 30 females (38\%), with median age of 32 (IQR: 26-39).

The permission to conduct the research was received from Rīga Stradiňš University (RSU) Ethics Committee, and all participants in the study gave their written consent to the examinations. Samples were received from Rīga Eastern Clinical University Hospital.

Peripheral blood mononuclear cell isolation. Peripheral blood mononuclear cells (PBMC) were isolated using Ficoll/Hypaque $1.077 \mathrm{~g} / \mathrm{ml}$ (Sigma Chemical Co, Munich, Germany) by the standard isolation protocol (Boyum, 1968).

For AIT patients monocyte isolation was performed by adherence, $10-15 \cdot 10^{6}$ PBMC were seeded per T25 cell culture flask, and allowed to adhere in a $5 \% \mathrm{CO}_{2}$ incubator at $37{ }^{\circ} \mathrm{C}$ for two hours in $5 \mathrm{ml}$ of culture medium (CM), which consisted of RPMI-1640 (Gibco, Germany) supplemented with $10 \%$ foetal bovine serum (Gibco, USA), $2 \mathrm{mM} \mathrm{L-}$ glutamine (Sigma Chemical Co, Munich, Germany), 100 $\mathrm{U} / \mathrm{ml}$ penicillin, and $100 \mu \mathrm{g} / \mathrm{ml}$ streptomycin (Sigma Chemical Co, Munich, Germany). Non-adherent cells were removed and the adherent cells were carefully washed, twice with CM. Adherent cells were left for 24 hours in a
$5 \% \mathrm{CO}_{2}$ incubator at $37{ }^{\circ} \mathrm{C}$. Harvested cells were washed three times with PBS and put into $1 \mathrm{ml}$ TRI-reagent (Life Technologies, USA) for following total RNA isolation. Leftover PBMC samples from the adherence protocol were used for DNA isolation.

Nucleic acid isolation, complementary DNA synthesis and quality determination. RNA from the harvested cells and from blood donor PBMC was extracted using TRIreagent, according to the protocol provided by the manufacturer (Life Technologies, USA). The integrity and quality of isolated RNA was tested in denaturing gel electrophoresis using NorthernMax ${ }^{\mathrm{TM}_{-}}$Gly Gel Prep/Running Buffer (ThermoFisher Scientific, USA) according to protocol of the manufacturer. Complementary DNA (cDNA) was synthesised using the innuSCRIPT One Step RT-PCR SyGreen Kit (Analytik Jena, Germany). DNA from PBMC was extracted using the phenol-chloroform method.

The quality of the isolated genomic DNA and synthesised cDNA, obtained from patient PBMCs and monocytes/macrophages, was determined by beta $(\beta)$-globin polymerase chain reaction (PCR) with appropriate primers (Vandamme et al., 1995).

Detection of HHV-6 genomic sequences and gene expression using nested PCR techniques. The HHV-6 genomic sequence in the DNA isolated from AIT patient PBMC was identified using nested PCR (nPCR) technique. PCR amplification of viral DNA was carried out in the presence of $1 \mu \mathrm{g}$ of PBMC DNA. HHV-6 was identified in accordance with Secchiero et al., 1995. Positive controls (HHV-6A and HHV-6B genomic DNA; Advanced Biotechnologies Inc, Columbia, MD, USA) and negative controls (DNA obtained from healthy HHV-6 negative blood donor and a sample without template DNA) were included in each experiment.

To identify active HHV-6 replication, HHV-6 U79/80 gene expression was determined using nPCR with cDNA as the template (Kondo et al., 2002), as U79/80 gene coded proteins have a role in viral DNA replication (Taniguchi et al., 2000). The following primer pairs were used: an outer primer pair $\mathrm{U} 79 / 80 \mathrm{~F} 2$ :

5' -CTCGGAGCCCGAGCTACGAAATCTG-3' and U79/80R2: 5' -GCAACAAGTCT GGCCCTAAGCTG-3', and an inner primer pair: U79/80F1:

5' -CGATGAACACAGAAAACGCTCG-3' and U79/80R1: 5' -GTAGAAGTCGGTGC TATGCCATC-3'. The PCR buffer and other reagents were in the same concentrations as in the nPCR described below.

To determine HHV-6 U12 and U51 gene expression, nPCR with cDNA as the template was performed (Kondo et al., 2002). The following primer pairs were used: an outer primer pair $\mathrm{U} 12 \mathrm{~F} 2$ :

5'-GAGTCCTCCCAACCATGGTGTTCAGC-3' and U12R2: 5'-CTGACGATTCTGATGGCGAGTTCTG-3' (for the HHV-6 U12); U51F2:

5'-CATTGCTTCGTTTCTTCGGGATGGAG-3' and U51R2: 5'-CGCGAGAAAACACTGTCCAGTCTCG-3' 
(for the HHV-6 U51); as well as an inner primer pair: U12F1: 5'-CATACAGATCCCCTATATAGCTATC-3' and U12R1: 5'-CCTCCAGTGAATGCGTAGACTAACG-3' (for the HHV-6 U12); U51F1:

5'-CCAGCCACCGCGGAGTTTTATGGC-3' and U51R1: 5'-CCAACGACCACGAAG-AGAAATAGGC-3' (for the HHV-6 U51).

All $\mathrm{nPCR}$ reactions were done in two rounds, each reaction had a volume of $50 \mu \mathrm{l}$ consisting of: $5 \mu \mathrm{L}$ of the extracted DNA sample or synthesised cDNA and $45 \mu \mathrm{L}$ of reaction mixture $(1 \times$ PCR buffer with KCl (Thermo Scientific, Fermentas, Lithuania), $0.2 \mathrm{mM}$ of dNTP (Thermo Scientific, Fermentas, Lithuania), $15 \mathrm{mM} \mathrm{MgCl}$ (Thermo Scientific, Fermentas, Lithuania), 2.5 units of Taq DNA polymerase (Thermo Scientific, Fermentas, Lithuania) and corresponding primer pairs with the concentration of $0.5 \mu \mathrm{M}$ ). Reaction was done in 35 cycles (denaturation at $95{ }^{\circ} \mathrm{C}$ for $30 \mathrm{~s}$, annealing at $62{ }^{\circ} \mathrm{C}$ for $30 \mathrm{sec}$, and elongation at $75{ }^{\circ} \mathrm{C}$ for 1 $\mathrm{min}$ ) for two rounds. A 10-min additional elongation step was done after the last cycle to ensure complete polymerisation.

HHV-6 load determination using quantitative PCR. AIT patient PBMC DNA samples that were positive for the presence of HHV-6 genome sequence were used for HHV-6 load detection using the HHV-6 Real-TM Quant (Sacace Biotechnologies, Italy) commercial kit in accordance with the manufacturer's instructions.

Statistical analysis methods. All statistical calculations and graphs were created using GraphPad Prism software version 6.0 for Windows (GraphPad Software, San Diego, CA, USA). Statistical differences in the prevalence of HHV-6 infection were assessed by the Fisher exact test. Statistical differences in viral load and serological results were tested using the Mann-Whitney test. Because most of the data was not distributed normally, results are expressed as median and interquartile range as a variability characteristic, and a $p$-value less than $0.05(p<0.05)$ was considered as statistically significant.

\section{RESULTS}

Detection of HHV-6 persistent infection in AIT patients' and blood donors' PBMC. HHV-6 genomic sequence frequency was significantly higher $(p=0.0001)$ in AIT patient PBMC DNA samples (24 out of $73 ; 33 \%$ ) in comparison to those of blood donors (6 out of 80; 7\%) (Fig. 1).

Detection of HHV-6 active infection (HHV-6 U79/80 gene expression). Markers of active HHV-6 infection (presence of HHV-6 U79/80 mRNA) were found in 8 of 73 (11\%) monocyte/macrophage RNA samples acquired from AIT patients. From 24 patient samples positive for the HHV-6 genomic sequence, 33\% contained markers of active HHV-6 infection. It was not possible to harvest blood donor PBMC for monocyte/macrophages in adherence to the protocol, as blood donor PBMC samples were collected

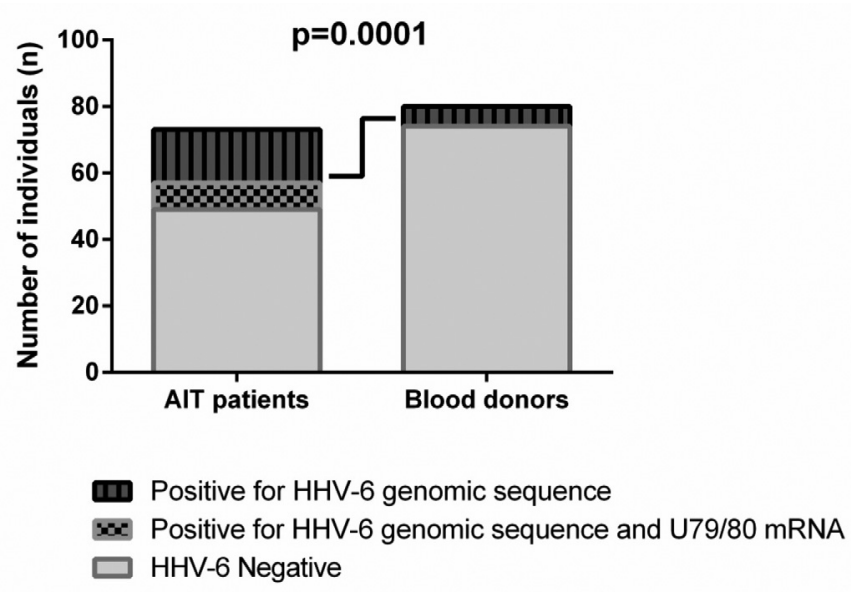

Fig. 1. Presence of human herpesvirus-6 (HHV-6) genome sequence and HHV-6 U79/80 mRNA (marker of active infection) in autoimmune thyroiditis (AIT) patient samples and blood donors (control group).

and stored in Tri-reagent before this study. That is why blood donor total RNA for active HHV-6 infection marker detection was isolated from PBMC. HHV-6 U79/80 mRNA was not found in any of the 6 blood donor samples positive for the HHV-6 genomic sequence (Fig. 1).

Detection of HHV-6 U12 and U51 gene expression. HHV-6 U12 mRNA was not found in any AIT patient or blood donor samples. HHV-6 U51 mRNA was found only in two out of $24(8 \%)$ AIT patient samples positive for the HHV-6 genomic sequence. None of the blood donor samples were positive for HHV-6 U51 mRNA.

Detection of HHV-6 load. Sensitivity of the HHV-6 RealTM Quant (Sacace Biotechnologies, Italy) commercial kit is about 5 viral copies. Detectable HHV-6 load was found in only 6 of 24 (25\%) AIT patient samples previously determined to be positive for the HHV-6 genomic sequence. The median HHV-6 load found in AIT patient samples was 5.246 (IQR: $2.026-21.41$ ) viral copies/ $/ 10^{6}$ cells. In contrast, no detectable HHV-6 load was found in blood donor samples (Fig. 2).

Only two of AIT patient samples that were positive for at least one of HHV-6 mRNAs (U12, U51 and/or U79/80) were with detectable viral load. Two samples positive for HHV-6 U51 mRNA had a viral load of 6.090 and 4.400 copies $/ 10^{6}$ cells.

\section{DISCUSSION}

From the beginning it was postulated that HHV-6 is a lymphotropic virus with primary tropism for CD4+ T cells, in which they replicate efficiently (Dockrell and Paya, 2001; Lusso, 2006). Later studies indicated the ubiquitous nature of HHV-6 and showed that HHV-6 genomic sequence could be found in almost every solid tissue and other peripheral blood subpopulations including monocytes/macrophages (Kondo et al., 2002; Chen and Hundall, 2006; Caselli et al., 2012). 


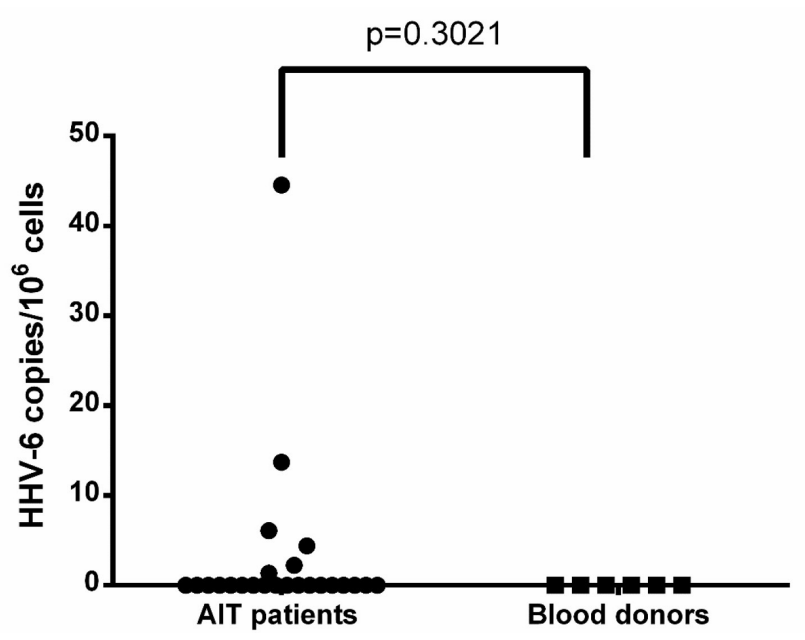

Fig. 2. The comparison of HHV-6 load between autoimmune thyroiditis (AIT) patient and blood donor samples.

For HHV-6 active infection, viremia is not typical and occurs only in acute cases, as the virus in most cases spreads from cell to cell. HHV-6 U51 is shown to be a positive regulator of virus replication in vitro, and may promote membrane fusion facilitating cell-cell spread of this highly cell-associated virus (Zhen et al., 2005). Such spread tactics could help HHV-6 to effectively escape immune responses and provoke autoimmune reactions (Mothes et al., 2010).

One study showed that during acute infection HHV-6 uses mainly monocytes/macrophages for the spread and expresses viral chemokine receptors U12 and U51, which might help to avoid immune responses. Monocyte/macrophage migration into an inflammation site might facilitate infection of solid tissues (Kondo et al., 2002). This makes monocytes/macrophages important mediators in delivering HHV-6 to its final destination, where the virus could persist.

Nowadays, more evidence indicates HHV-6 as a very important factor in AIT development (Rizzo et al., 2016; Caselli et al., 2017; Sultanova et al., 2017). Our previous studies showed almost $100 \%$ incidence of the HHV-6 genomic sequence in thyroid gland tissues acquired from AIT patients and insignificant presence in peripheral blood (Sultanova et al., 2016; 2017). Also, in-depth study on PBMC subpopulation cell sorting showed absence of HHV-6 genomic sequence in primary target cells - CD4+ and CD8+ $\mathrm{T}$ lymphocytes (Sultanova et al., 2016). The aim of this study was to investigate the possible use of monocytes/ macrophages as mediators by HHV-6 for thyroid gland infection in the case of autoimmune thyroiditis. The results of this study show significantly higher presence $(p=0.0001)$ of HHV-6 genomic sequences in AIT patient PBMC samples than in the control group (33\% vs $7 \%$, respectively), and in addition presence of the HHV- 6 active infection marker (HHV-6 U79/80 mRNA) was found only in AIT patient monocyte/macrophage samples (8 out of $24 ; 33 \%$ ). That means that HHV-6 has relatively higher activity in AIT patient monocytes/macrophages than in healthy indi- viduals. The obtained results on viral load also support this statement. In the majority of HHV-6 positive PBMC samples we were unable to determine the viral load, but this can be considered as normal for HHV-6. Guidelines for virus testing published on the HHV-6 Foundation website (Anonymous, 2019) indicate that its load usually is not detectable in peripheral blood.

Only two AIT patient samples were positive on HHV-6 U51 mRNA. Nevertheless, involvement of expression of this gene in AIT development cannot be excluded.

Overall, the results of this study indicate the possibility of monocytes/macrophages being used by HHV-6 as mediators for thyroid gland infection and their potentially important role in AIT development. However, to make final conclusions additional study is required.

\section{ACKNOWLEDGEMENTS}

This work was supported by the National Research Programme "Biomedicine for the Public Health" (BIOMEDICINE)

\section{REFERENCES}

Ablashi, D, Agut, H, Alvarez-Lafuente, R, Clark, D. A., Dewhurst, S., DiLuca, D., Flamand, L., Frenkel, N., Gallo, R., Gompels, U. A., Höllsberg, P., Jacobson, S., Luppi, M., Lusso, P., Malnati, M., Medveczky, P., Mori, Y., Pellett, P. E., Pritchett, J. C., Yamanishi , K., Yoshikawa, T. (2014). Classification of HHV-6A and HHV-6B as distinct viruses. Arch Virol., 159 (5), 863-870.

Anonymous (2019). Overview on testing for HHV-6 infection. Available from: https://hhv-6foundation.org/patients/hhv-6-testing-for-patients (accessed 14.02.2019).

Boyum, A. (1968). Separation of leukocytes from blood and bone marrow. Introduction. Scand. J. Clin. Lab. Invest. Suppl., 97, 7-11.

Caselli, E., D’Accolti, M., Soffritti, I., Zatelli, M. C., Rossi, R., degli Uberti, E., Di Luca, D. (2017). HHV-6A in vitro infection of thyrocytes and T cells alters the expression of miRNA associated to autoimmune thyroiditis. Virol. J., 14, 3.

Chapenko, S., Millers, A., Nora, Z., Logina, I., Kukaine, R., Murovska, M. (2003). Correlation between HHV-6 reactivation and multiple sclerosis disease activity. J. Med. Virol., 69 (1), 111-117.

Chen, T., Hudnall, S. D. (2006). Anatomical mapping of human herpesvirus reservoirs of infection. Mod. Pathol., 19 (5), 726-737.

Costa, F. A, Soki, M. N, Andrade, P. D, Bonon, S. H, Thomasini, R. L., Sampaio, A. M., Ramos, M. de C., Rossi, C. L., Cavalcanti, T. C., Boin, I. de F, Leonard, M., Leonard, L. S., Stucchi, R. B., Costa, S. C. (2011). Simultaneous monitoring of CMV and human herpesvirus 6 infections and diseases in liver transplant patients: One-year follow-up. Clinics (Sao Paulo), 66 (6), 949-953.

Dockrell, D. H., Paya, C. V. (2001). Human herpesvirus-6 and -7 in transplantation. Rev. Med. Virol., 11, 23-36.

Grima, P., Chiavaroli, R., Calabrese, P., Tundo, P. (2008). Severe hepatitis with autoimmune features following a HHV-6: A case report. Cases J., 1 (1), 110 .

Kondo, K., Kondo, T., Shimada, K., Amo, K., Miyagawa, H., Yamanishi, K. (2002). Strong interaction between human herpesvirus 6 and peripheral blood monocytes/macrophages during acute infection. J. Med. Virol., 67 (3), 364-369. 
Lusso, P. (2006). HHV-6 and the immune system: Mechanisms of immunomodulation and viral escape. J. Clin. Virol., 37 (1), 4-10.

Mothes, W., Sherer, N. M., Jin, J., Zhong, P. (2010) Virus cell-to-cell transmission. J. Virol., 84 (17), 8360-8368.

Murakami, Y., Tanimoto, K., Fujiwara, H., An, J., Suemori, K., Ochi, T., Hasegawa, H., Yasukawa, M. (2010). Human herpesvirus 6 infection impairs Toll-like receptor signaling. Virol. J., 7, 91.

Rizzo, R., Zatelli, M. C., Rotola, A., Cassai, E., Degli Uberti, E., Di Luca, D., Caselli, E. (2016). Increase in peripheral CD3-CD56brightCD16- natural killer cells in Hashimoto's thyroiditis associated with HHV-6 infection. Adv. Exp. Med. Biol., 897, 113-120.

Secchiero, P., Carrigan, D. R., Asano, Y., Benedetti, L., Crowley, R. W., Komaroff, A. L., Gallo, R. C., Lusso, P. (1995). Detection of human herpesvirus 6 in plasma of children with primary infection and immunosuppressed patients by polymerase chain reaction. J. Infect. Dis., 171 (2), 273-280.

Sultanova, A., Cistjakovs, M., Cunskis, E., Todorova, K., Russev, R., Murovska, M. (2016). Thyrocytes as the target cells for Hhv-6 infection in patients with autoimmune thyroiditis. Proc. Latvian Acad. Sci. Section B, 70 (4), 160-164.

Sultanova, A., Cistjakovs, M., Gravelsina, S., Chapenko, S., Roga, S., Cunskis, E., Nora-Krukle, Z., Groma, V., Ventina, I., Murovska, M.
(2017). Association of active human herpesvirus-6 (HHV-6) infection with autoimmune thyroid gland diseases. Clin. Microbiol. Infect., 23 (1), 50.e1-50.e5.

Taniguchi, T., Shimamoto, T., Isegawa, Y., Kondo, K., Yamanishi, K (2000). Structure of transcripts and proteins encoded by U79-80 of human herpesvirus 6 and its subcellular localization in infected cells. Virology, 271 (2), 307-320.

Tejada-Simon, M. V., Zang, Y. C., Hong, J., Rivera, V. M., Zhang, J. Z. (2003). Cross-reactivity with myelin basic protein and human herpesvirus-6 in multiple sclerosis. Ann. Neurol., 53 (2), 189-197.

Vandamme, A. M., Fransen, K., Debaisieux, L., Marissens, D., Sprecher, S. Vaira, D., Vandenbroucke, A. T., Verhofstede, C. (1995). Standardisation of primers and an algorithm for HIV-1 diagnostic PCR evaluated in patients harbouring strains of diverse geographical origin. The Belgian AIDS Reference Laboratories. J. Virol. Methods, 51 (2-3), 305-316.

Yagasaki, H., Kato, M., Shimizu, N., Shichino, H., Chin, M., Mugishima, H. (2011). Autoimmune hemolytic anemia and autoimmune neutropenia in a child with erythroblastopenia of childhood (TEC) caused by human herpesvirus-6 (HHV-6). Ann. Hematol., 90 (7), 851-852.

Zhen, Z., Bradel-Tretheway, B., Sumagin, S., Bidlack, J. M., Dewhurst, S (2005). The human herpesvirus $6 \mathrm{G}$ protein-coupled receptor homolog U51 positively regulates virus replication and enhances cell-cell fusion in vitro. J. Virol., 79 (18), 11914-11924.

Received 31 October 2018

Accepted in the final form 11 February 2019

\section{MONOCĪTI/MAKROFĀGI DARBOJAS KĀ MEDIATORI VAIROGDZIEDERA AUDU INFICĒŠANĀ AR HHV-6 AUTOIMŪNĀ TIREOIDĪTA PACIENTU VIDŪ}

Šì pētījuma mērkis bija izpētīit cilvēka herpesvīrusa-6 (HHV-6) spēju izmantot monocītus/makrofāgus kā mediatorus vairogdziedera audu inficēšanā autoimūnā tireoidīta (AIT) pacientu vidū. Pētījumā tika iekḷauti 73 pacienti ar autoimūno tireoidītu. Kontroles grupu veidoja 80 asins donori. Tika veikta perifēro asinnu mononukleāro šūnu (PBMC) izolācija, un AIT pacientu gadījumā tālāk tika atdalīti monocîti/makrofāgi, izmantojot šūnu adhēziju. HHV-6 klātbūtne PBMC DNS paraugos tika detektēta, veicot nested PCR (nPCR). AIT pacientu monocītu/makrofāgu paraugiem un asins donoru PBMC paraugiem aktīvās infekcijas markieru (U79/80) un hemokīnu receptoru (U12 un U51) gēnu ekspresija tika noteikta, veicot reversās transkripcijas PCR. HHV-6 slodze tika noteikta, izmantojot kvantitatīvo-PCR. HHV-6 genoma klātbūtne autoimūnā tireoidīta pacientu paraugos tika detektēta ievērojami biežāk, salīdzinot ar asins donoru paraugiem. Aktīvas infekcijas markieri tika atrasti 8 (11\%) autoimūnā tireoidīta pacientu monocītu/makrofāgu paraugos un nevienā no kontroles grupas PBMC paraugiem. Līdzīgi arī HHV-6 U51 mRNS tika atrasta tikai autoimūnā tireoidīta pacientu vidū — 2 no 24 (8\%) HHV-6 pozitīivajiem paraugiem. Tā kā HHV-6 genoma sekvenču klātbūtne ievērojami biežāk tika detektēta autoimūnā tireoidīta pacientu paraugos un aktīvas infekcijas markkieri tika atrasti monocītos/makrofāgos, pētījuma rezultāti norāda uz iespējamo monocītu/makrofāgu kā mediatoru lomu HHV-6 infekcijai vairogdziedzera audos. 